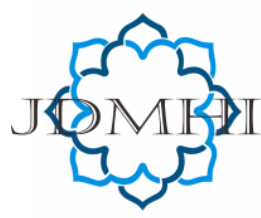

email: jdmhi@walisongo.ac.id

Journal of Digital Marketing and Halal Industry

ISSN: 2716-4810 (print) ISSN: 2716-4802 (online)

\title{
The Influence of Brand Trust, Brand Familiarity, and Brand Experience on Brand Attachments
}

\section{Dede Barijan, Endah Pri Ariningsih, Fitri Rahmawati}

Universitas Muhammadiyah Purworejo, Indonesia

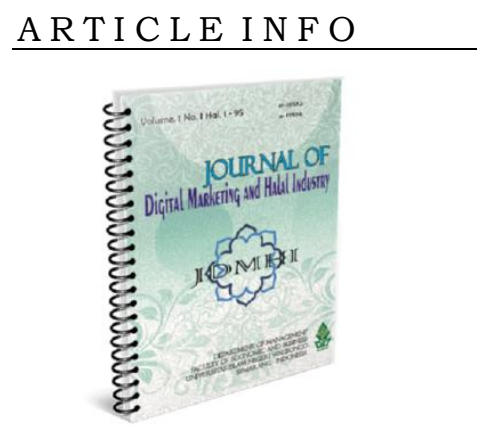

Article history:

Received 29 January 2021

Accepted 22 April 2021

Published 30 April 2021

Keywords:

Brand Trust, Brand Familiarity,

Brand Experience, Brand

Attachment
A B S T R A C T

The development of technology in the automotive world today has progressed very rapidly. Thus, automotive companies must compete in winning market share in Indonesia. Business competition brings companies competing to produce products that consumers need and want. This study aims to determine the effect of brand trust on brand attachment, brand familiarity on brand attachment, and brand experience on brand attachment. Sampling using a purposive sampling technique. The data collection instrument used a questionnaire with a Likert scale. The questionnaire has been tested and has met the validity and reliability requirements. Data analysis was performed using multiple linear regression analysis. The results of data analysis show that brand trust has a positive effect on brand attachment, brand familiarity has a positive effect on brand attachment, and brand experience has a positive effect on brand attachment. Thus it can be concluded that brand trust, brand familiarity, and brand experience significantly influence brand attachment partially.

@2021 Journal of Digital Marketing and Halal Industry

\section{Introduction}

Current technological developments have progressed very rapidly. Technology is getting more sophisticated over time, especially in the transportation sector. Therefore, transportation companies are now increasingly creative and innovative in creating a product with technology. The development of motorbike engine technology at this time is very fast because every manufacturer is competing to develop their creations, especially in machine technology to increase the company's competitiveness. Marketing plays an important role in the business world because marketing is related to activities to

* Corresponding author.email: endah@umpwr.ac.id DOI: http://dx.doi.org/10.21580/jdmhi.2021.3.1.7440 
predict or anticipate the needs and desires of consumers and is also related to the flow of products in the form of goods and services from producers to consumers to achieve company goals, namely making a profit. A very heterogeneous market will provide opportunities for companies that can take advantage of it.

Each product will try to fight over the market. But marketers also realize that they will not be able to serve the existing market. There are too many different types of consumers with many needs, so it requires more effort to fight over the market. By dividing a very heterogeneous market into groups or market segments that are more homogeneous, marketers will find it easier to serve consumers. The sophistication of technology makes it easier for market players to imitate the product designs or production processes of their competitors. This causes so many products that are very special or difficult to obtain, now they become commodities that can be easily obtained. Marketing is required to always offer added value to customers in such a way that competitors cannot easily imitate it. The increasingly complex business competition conditions expose consumers to accelerating the purchasing decision-making process and at the same time reducing the risks arising from these decisions. With the development of information technology, society is becoming increasingly critical, including the ability to criticize messages received. The importance of the role of brands in the consumer decisionmaking process makes marketers place the brand as one of the most important company assets.

Currently, competition in the automotive world is getting tougher, especially motorcycle competition. The increase in motorbikes is due to the increasing consumer demand for modes of transportation and daily activities. The Honda and Yamaha brands are automotive companies that dominate the Indonesian market. However, compared to Honda, Yamaha has always lagged in sales every year. Nowadays, many brands are offered by companies with their respective advantages. Several brands competing in the market such as Honda, Kawasaki, Suzuki, and TVs. The various brands offered to make consumers have to make several considerations in choosing a brand that suits their needs and desires. Brand attachment can be defined as a psychological variable that shows a lasting and unchanging affective reaction to a brand, expressing a psychological bond with the brand (Lacoeuilhe, 2000: 66). Furthermore, according to Keller (2013: 102) brand attachment can be defined as the level of loyalty that consumers feel towards a brand.

According to Chinomona and Maziriri (2017) brand attachment is influenced by brand trust, brand familiarity, and brand experience. On the practical side, brand trust, brand familiarity, and brand experience have had a strong positive influence on brand attachment. The influence of each of these three factors can stimulate a higher brand attachment to consumers. The Yamaha company was founded in 1887, Torakusu Yamaha founded a company that made organ pianos at that time, the company was called Yamaha Corp Nippon Gakki. Then, Yamaha is famous for its world-renowned musical instrument makers. The logo was created on June 1, 1955. After that, another new company called Yamaha Motor Corp was established, which was separate from Yamaha Corp Nippon 
Gakki, but remained in one group. The motor that was produced by Yamaha for the first time was a single cylinder 2 stroke motor with 125 ccs which this motorbike mimics the DKW 125 cc. Then Yamaha developed at a rapid pace at that time, 1959 came out of motorsport that was produced by Yamaha for the first time. The motorsport is known as the YDSI motorbike with a 5-speed gearbox. In 1960, Yamaha's production increased 6 times until it could produce 138 thousand motorbikes (www.federaloil.co.id).

Until now, the Yamaha brand has become the choice of consumers from the many motorcycle brands on the market. Consumers trust (trust) in the Yamaha brand. The location of its branches that have spread throughout Indonesia makes it easy for consumers to reach them. Yamaha is a good brand/brand in the eyes of consumers, thus making sales increase. Yamaha spends a lot of money on sponsoring Moto GP to maintain the image that their product or brand is a high-quality and high-performance product (www.motorek.wordpress.com).

Based on the results of research by Chinomona \& Maziriri (2017), it is known that brand attachment is significantly influenced by brand experiences. Meanwhile, a higher level of brand trust can be expected to lead to a stronger brand attachment. Based on the results of research by Chinomona \& Maziriri (2017), it is known that brand trust has a significant effect on brand attachment; So that research on brand trust, brand familiarity, brand experience, and their impact on brand attachment becomes interesting to do. Based on the background described, the purpose of this study is to examine the effect of brand trust, brand familiarity, and brand experience on brand attachment on Yamaha brand motorbikes in Kebumen City.

\section{Literature Review}

\section{Brand}

Creating a strong brand provides many benefits for the company. The American Marketing Association in Kotler \& Keller (2013) defines a brand or brand as, "A name, term, sign, symbol, or design, or a combination of them, intended to identify the goods or services of one seller or group of sellers. and to differentiate them from those of competitors ". It can be interpreted that a brand is a name, term, sign, symbol, design, or a combination of all that is intended to identify a product from one seller or a group of sellers and as a differentiator from competing products. According to Aaker (1997), a brand is a distinguishing name and/or symbol (logo, stamp, or packaging) to identify the goods or services of a particular seller or group of sellers, thereby distinguishing them from goods and services produced by consumers. competitors. Keller (2013) states that there are several criteria in selecting brand elements, including:

1. Memorable

Easy to remember is a necessary condition in building a brand image to achieve a high level of brand awareness. An impressive brand element catches attention and is easy to remember or recognize.

2. Meaningful

Brand elements are expected to have a good meaning regarding general information about the function or service of the product as well as specific information about the benefits of the 
brand.

3. Likable

Consumers will generally look for products that catch their attention.

4. Transferable

The transferable element is a step in which the brand element can add brand equity to a new product or new market.

5. Adaptable

The more adaptable and flexible a brand element is, the easier it will be to update it.

6. Protectable

Marketers must select elements of the brand that can be legally protected and legally register it with the right legal entity and have a legal trademark. Kotler \& Keller (2012) argue that brands have several roles, namely:

a. Brands make it easy to order and trace a product.

b. Brands help to organize inventory and accounting records.

c. Trademarks offer legal protection for aspects or uniqueness of their products.

d. The brand signifies a certain quality so that satisfied buyers will make repeat purchases.

e. The brand becomes a strong suggestion for securing a competitive advantage.

\section{Benefits and Advantages}

Brand benefits create a perception and brand advantages are one of the boosters of the company's progress. According to Alma (2011) Brands or brands will provide benefits to several parties:

1. Manufacturer or Seller a. Make it easy for sellers to process orders and reduce problems.

b. Provide opportunities for sellers to classify the market into certain segments.

c. Assist the seller in classifying the market into certain segments.

d. Company image can be fostered by having a good brand.

e. Provides defense against fierce price competition.

2. Buyers or consumers

a. Can distinguish products without having to examine them carefully.

b. Consumers get information about products.

c. Increase efficiency.

For companies, the brand acts as an identification tool that helps the process of product management, inventory maintenance, and accounting records. Trademarks also provide legal protection for companies in the form of registered trademarks. Just as the production process is protected by patents or the product design is protected by copyright. Another contribution that a brand makes for the company is that it guarantees a certain level of quality so that consumers who are satisfied with the product's performance at a certain level can easily choose the same brand when the consumer makes a repeat purchase.

\section{Brand Attachment}

A simpler definition of brand attachment is a bond that is full of emotions or emotional connection between a person and a brand. Consumers tend to be emotionally attached to several brands, feeling a connection, passion, or affection for them, to a degree that can vary from brand to brand. Brand attachment is a 
basic characteristic of emotional attachment. Brand attachment reflects an attachment to a brand and is a psychological variable that shows an irreversible affective relationship with a brand and states the psychological closeness of consumers with the brand (Aureliano-Silva, L., 2018). Attachments are emotional and affective bonds that consumers build concerning a particular brand. Customers tend to personify the brands they like and thus build close affiliations with them. Brand attachment is an important construct in describing the strength of the bonds that connect consumers to a brand because it must influence behavior that fosters brand profitability and consumer lifetime value.

Conceptually, brand attachment is similar to ownership attachment when considering a brand as a source of emotions, self-identity, and personal historical values. Brand attachment theory stems from consumer behavior research, where areas of interest are related to brand relationships and loyalty. Brand attachment reflects strong and longlasting psychological and emotional brand relationships that result from feelings of friendship and dependence on the brand. Brand Attachment A simpler dBrand attachment can also be considered as the strength of the bond that connects the brand with oneself. Brand attachment is a construct that reflects the bonds that connect consumers with certain brands and involves positive feelings towards the brand. (Chinomona, Richard \& Maziriri, 2017). Meanwhile, Yuan and Lei (2017) show that brand attachment is a relationship-based concept that reflects an emotional bond between a person and a brand. The brand attachment consists of three emotional components: compassion, passion, and connection. Affection is characterized by the emotional items of love, kindness, and peace. Passion is characterized by pleasure and interest.

Brand attachment can be defined as a psychological variable that shows a lasting and unchanging affective reaction to a brand, expressing a psychological bond with the brand (Lacoeuilhe, 2000: 66). According to Keller (2013: 102) brand attachment is the level of loyalty that consumers feel towards the brand. Meanwhile, according to Louis and Lombart (2010: 118), brand attachment is an emotional relationship between consumers and a brand. Lau and Lee (1999: 343) define trust as a person's willingness to depend on other parties with certain risks. Trust also means the belief that someone will find what they want from others, not what they are afraid of (Deutsch in Delgado and Munuera, 2005). Meanwhile, according to Moorman et al., In Chaudhuri and Holbrook, (2002) Brand trust means that consumers are generally willing to rely on the brand's ability to carry out its functions (Moorman et al., In Chaudhuri and Holbrook, 2002). Familiar brand

According to Cannon and Carthy (2008: 300) brand familiarity means how well consumers recognize and accept a company's brand. According to Keller (2008: 55) Brand familiarity is a condition in which a brand or product can be known or known well by consumers. Meanwhile, according to Nguyen and Gizaw (2014), brand familiarity is the extent to which information is available about brands that make consumers confident to buy these products, and brand familiarity has an important role in a consumer's purchase interest to be tied to a particular brand. 


\section{Brand Experience}

According to Brakus et al., (2009: 70) brand experience is defined as the sensation, feeling, cognition, and consumer responses generated by the brand, related to the stimuli caused by the brand design, brand identity, marketing communications, people, and the environment the brand is marketed. Furthermore, brand experience is defined as sensation, feeling, cognition, and behavioral responses generated by brand-related stimuli which are part of the design and brand identity, packaging, communication, and the environment (Evans, 2011: 71). The brand experience begins when consumers start looking for products, make purchase decisions after consuming the product, and other marketing strategies carried out by the brand regarding the products or services they offer.

\section{Hypothesis Development}

The Influence of Brand Trust on Brand Attachments

When consumers believe that the company puts the interests of consumers above the interests of the company and the company tries hard to improve customer welfare, customers will become more emotional to tie themselves up because they trust the company's efforts (Park et al., 2006: 208). The results of research conducted by Chinomona and Maziriri (2017), and Furrahmi and Chan (2018) show that brand trust has a positive and significant effect on brand attachment. So, the first hypothesis of this study is:

H1: Brand trust has a positive effect on Brand attachment.

The Influence of Brand Familiarity on Brand Attachment
Good familiarity will increase consumers' emotional attachment to the brand so that consumers will become familiar with the brand when they feel that the brand matches their expectations (Heckler et al., 1994). The results of research conducted by Chinomona and Maziriri (2017) and Furrahmi and Chan (2018) state that brand family has a positive and significant effect on brand attachment. The results showed that there was a significant influence of the brand familiarity variable on brand attachment. So, the second hypothesis of this study is:

H2: Brand familiarity has a positive effect on Brand attachment.

The Influence of Brand Experience on Brand Attachments.

Naidoo (2011: 30) states that every time a consumer interacts with a brand it results in a positive, negative, or neutral experience. Positive experiences that consumers have with certain brands are a driving factor for consumers to be tied to certain brands (Mkhize, 2010: 63). The results of research conducted by Chinomona and Maziriri (2017) show that there is a positive and significant influence of the brand experience variable on brand attachment. So, the third hypothesis of this study is:

H3: Brand experience has a positive effect on Brand attachment.

\section{The Method, data, and analysis}

This research is survey research. According to Hartono (2013: 140), the survey method is a method of collecting primary data by using questions to individual respondents. In this study, the population will be all consumers of 
Yamaha motorcycles in Kebumen Regency. Sampling using purposive sampling technique, namely the technique of taking samples from the population-based on certain criteria (Hartono, 2013: 98). The criteria are as follows: (a) Consumers who live in Kebumen Regency and already use Yamaha brand motorbikes. (b) Consumers are at least 18 years old with the consideration that these consumers are adults and able to understand statements and be able to provide opinions on statements contained in the questionnaire (Kasali, 2003: 200).

\section{Operational Definition of Variables}

a. Brand Attachment

Brand attachment can be defined as a psychological variable that shows a lasting and unchanging affective reaction to a brand, expressing a psychological bond with the brand (Lacoeuilhe, 2000: 66). Thomson (2005) reveals indicators regarding brand attachment, namely: affection, passion, connection (linkage).

b. Brand Trust

The definition of brand trust in this study refers to the opinion of Lau and Lee (1999: 344), namely the willingness of consumers to trust a brand even though the brand is risky because consumers have the hope that the brand can bring positive things for it. The brand trust indicator refers to the opinion of Chaudhuri and Holbrook (2001: 87), namely: trust, reliability, honesty, and safe.

c. Familiarity brand

According to Cannon and Carthy (2008: 300) brand familiarity means how well consumers recognize and accept a company's brand. The indicators used are a combination according to Porral \& Mangin (2016), Simonin \& Ruth (1998), and Adamantios et al., (2005) in this study: distinguish, associate, had heard, and knowledgeable.

d. Brand Experience

According to Brakus et al., (2009: 70) brand experience is defined as the sensation, feeling, cognition, and consumer responses generated by the brand, related to the stimuli caused by the brand design, brand identity, marketing communications, people, and the environment the brand is marketed. The indicators of brand experience used in this study are sensory, affection, behavior, and intellectual.

\section{Result and Discussion}

The results of multiple linear regression analysis

Table 1. Multiple Linear Regression Analysis

\begin{tabular}{cccc}
\hline Variable & $\begin{array}{c}\text { Standardized } \\
\text { Coefficient } \\
\text { Beta }\end{array}$ & $\begin{array}{c}\text { Significance } \\
\text { (p-value) }\end{array}$ & Keterangan \\
\hline $\begin{array}{c}\text { Brand } \\
\text { Trust (X1) } \\
\text { Brand }\end{array}$ & 0,183 & 0,039 & $\begin{array}{c}\text { Positif, } \\
\text { Signifikan } \\
\text { Positif, }\end{array}$ \\
$\begin{array}{c}\text { Familiarity } \\
(\mathrm{X} 2)\end{array}$ & 0,177 & 0,043 & $\begin{array}{c}\text { Signifikan } \\
\text { Brand }\end{array}$ \\
$\begin{array}{c}\text { Experience } \\
(\mathrm{X} 3)\end{array}$ & 0,271 & 0,002 & $\begin{array}{c}\text { Positif, } \\
\text { Signifikan }\end{array}$ \\
\hline
\end{tabular}

Source: Primary data processed (2020).

Based on table 1, the multiple linear regression line equation models in this study are as follows:

$\mathrm{Y}=0.183 \mathrm{X} 1+0.177 \mathrm{X} 2+0.271 \mathrm{X} 3$ 
The equation above can be explained as follows:

a. $\quad \mathrm{b} 1=0.183$, meaning that brand trust $(\mathrm{X} 1)$ has a positive influence on brand attachment (Y). This result means that the higher the brand trust from consumers, the more brand attachment will be.

b. $\quad$ b2 $=0.177$, meaning familiarity brand (X2) has a positive influence on brand attachment (Y). These results can be interpreted that the stronger the brand familiarity of consumers to the brand, the brand attachment will increase.

c. $\mathrm{b} 3=0.271$, meaning that brand experience $(\mathrm{X} 3)$ has a positive influence on brand attachment (Y). This result means that the more brand experience consumers get from the brand, the more brand attachment will be.

\section{Discussion}

Brand trust has a positive and significant effect on brand attachment. The results of data analysis show that the regression coefficient value of the brand trust variable (X1) is 0.183 , which means that the brand trust variable (X1) has a positive effect on brand attachment (Y) and the significance value is 0.039 ( $\mathrm{p}$-value $<0.05)$. This shows that there is a positive and significant influence between brand trust (X1) on brand attachment (Y). Therefore, it can be concluded that the first hypothesis (H1) proposed in this study can be accepted. The acceptance of the first hypothesis (H1) in this study is because respondents have more confidence in Yamaha motorbikes. Consumer confidence in the Yamaha brand can be seen from the number of consumers who prefer to use Yamaha brand motorbikes over other brands. The Yamaha brand is a brand that is well known and recognized by consumers because it is trustworthy, reliable, and safe to use so that consumers do not feel deceived by the specifications offered by the media. These results prove that consumers have a high level of brand trust in the Yamaha brand so that consumers' attachment to the Yamaha brand is also increasing, even though consumers are faced with many alternatives from other brands.

In addition, the acceptance of the first hypothesis in this study is following the opinion of Lau and Lee (1999: 343) defining trust as a person's willingness to depend on other parties with certain risks. In addition, according to Park et al., (2006: 208), when consumers believe that the company puts the interests of consumers above the interests of the company and the company tries hard to improve customer welfare, customers will become more emotional to tie themselves up because they trust the company's efforts. . In addition, this research is supported by the results of research conducted by Chinomona and Maziriri (2017), Furrahmi and Chan (2018), Purbasari and Purnamasari (2014), Widikusyanto (2014).

\section{Brand familiarity has a positive and significant effect on brand attachment}

The results of data analysis show that the regression coefficient value of the brand familiarity variable $(\mathrm{X} 2)$ is 0.177 , which means that the brand familiarity variable (X2) has a positive effect on brand attachment (Y) and the significance value is 0.043 ( $\mathrm{p}$-value $<0.05$ ). This shows that there is a positive and significant influence between brand family (X2) on brand attachment (Y). Therefore, it 
can be concluded that the second hypothesis (H2) proposed in this study is acceptable. The acceptance of the second hypothesis $(\mathrm{H} 2)$ in this study is because respondents who use Yamaha motorbikes are very familiar with the design and advantages of Yamaha motorbikes. In addition, respondents know the specific differences between Yamaha motorcycles and other brands. Consumers who use Yamaha brand motorbikes are very familiar with the existence of the Yamaha brand because the Yamaha brand is part of PT Yamaha Indonesia Motor Manufacturing which is also known to produce motorbikes so that people are easily recognized and remembered by the public. PT Yamaha Indonesia Motor Manufacturing has carried out promotions through the display of advertisements in various media continuously so that consumers recognize and accept the brand which aims to attract more consumers to be tied to the Yamaha brand and to know the advantages of the Yamaha brand specifically so that consumers are interested in using the Yamaha brand compared to with other brands.

These results prove that the Yamaha brand has succeeded in making a good impression on the minds of consumers so that consumers are very familiar with Yamaha brand motorbikes. In addition, the acceptance of the second hypothesis in this study is following the opinion of Cannon and Carthy (2008: 300), that brand familiarity means how well consumers recognize and accept a company's brand. Audiences tend to buy familiar brands because they feel safe with something consumers know or know well. In addition, this research is supported by the results of research conducted by Chinomona and Maziriri (2017), Furrahmi and Chan (2018), Purbasari and Purnamasari (2014),
Widikusyanto (2014).

H3: Brand experience has a positive and significant effect on brand attachment.

The results of data analysis show that the regression coefficient value of the brand experience variable (X3) is 0.271 , which means that the brand experience variable (X3) has a positive effect on brand attachment (Y) and the significance value is 0.002 ( $p$-value $<0.05)$. This shows that there is a positive and significant influence between a brand experience (X3) on brand attachment (Y). Therefore, it can be concluded that the third hypothesis (H3) proposed in this study can be accepted. The acceptance of the third hypothesis (H3) in this study is because Yamaha motorbikes have been able to provide brand experience to respondents through a strong design impression and driving comfort. This can be seen from the number of consumers who use Yamaha brand motorbikes.

The experience of consumers using Yamaha brand motorbikes can create a strong emotional bond between consumers and the Yamaha brand. The Yamaha brand has been able to provide experiences that stimulate consumer curiosity through product specifications, brand design, and type of motorbike, resulting in a positive experience. These results prove that the Yamaha brand has succeeded in providing a good brand experience and is valued positively by consumers. In addition, the acceptance of the third hypothesis in this study is following the opinion of Brakus et al., (2009: 70), that brand experience is defined as the sensation, feeling, cognition, and consumer responses generated by the brand, related to the stimuli caused by brand design, identity. brand, 
marketing communications, people, and the environment the brand is marketed to. In addition, this research is supported by the results of research conducted by Chinomona and Maziriri (2017), Furrahmi and Chan (2018), Purbasari and Purnamasari (2014), Widikusyanto (2014).

\section{Conclusion}

Based on the results of research and discussion of the influence of brand trust, familiarity brand, brand experience on brand attachment, it can be concluded that brand trust has a positive effect on brand attachment, meaning that the higher brand trust in Yamaha brand motorbikes can increase consumer brand attachment on Yamaha brand motorbikes. Therefore, companies need to pay attention to increasing consumer brand trust. The strategy to increase consumer brand trust in the Yamaha brand can be done by increasing consumer confidence and conforming to the specifications for the product type of the Yamaha brand, to increase brand trust in the Yamaha brand. Brand familiarity has a positive effect on brand attachment, meaning that the more familiar consumers are with a brand, the more attached consumers will be to the brand. Therefore, Yamaha companies must continue to communicate Yamaha brand motorbikes through advertisements and sales promotions via the internet by improving SEO (Search Engine Optimization), so that potential consumers or users when seeing/hearing the Yamaha brand will be familiar or familiar with the Yamaha brand. Brand experience has a positive effect on brand attachment, meaning that the more positive experiences consumers have about a brand, the brand can continue to be felt by consumers both through sensory, affection, behavior, and intellect so that it will lead to brand attachment.

\section{Recommendations}

Therefore, the Yamaha company must continue to give a good impression to Yamaha brand motorcycle consumers regarding the comfort and quality of the specifications offered by PT YIMM so that consumer interaction with a brand increases, so that consumers have a positive experience with the Yamaha brand.

\section{References}

Brakus, J.J., Schmitt, B. H. \& Zarantonello, L. (2009). Brand experience: What is it? How is it measured? Does it affect loyalty?. Journal of Marketing. No.73, pp. 52-68.

Belaid, S. \& Temessek, B. A. (2011). The role of attachment in building consumerbrand relationships: an empirical investigation in the utilitarian consumption context. Journal of Product \& Brand Management. Vol. 20. No. 1, pp. 37-47.

Chinomona dan Maziriri. 2017. The Influence of Brand Trust, Brand Familiarity and Brand Experience on Brand Attachment: A Case of Consumers in the Gauteng Province of South Africa. Journal of Economics and Behavioral Studies. Vol. 9. No. 1, pp. 69-81.

Furrahmi dan Chan. (2018). Pengaruh Kepercayaan Merek, Keakraban Merek, dan Pengalaman Merek Terhadap Keterikatan Merek Pada Konsumen 
Sepeda Motor Yamaha Di Banda Aceh. Jurnal Ilmiah Mahasiswa Ekonomi Manajemen. Vol. 3. No. 2, pp. 22-35.

Ghozali, Imam. 2013. Aplikasi Analisis Multivariate dengan Program SPSS. Semarang: Badan Penerbit Universitas Diponegoro.

Hartono, Jogiyanto. 2013. Metodologi Penelitian Bisnis. Salah Kaprah dan Pengalaman-Pengalaman. Edisi Kelima. Yogyakarta: BPFE.

Hartini, Sri. 2012. Perilaku Pembelian Smartphone: Analisis Brand Equity dan Brand Attachment. Jurnal Mitra Ekonomi dan Manajemen Bisnis. Vol. 3. No. 1, pp. 75-86.

Kasali, Rhenald. 2003. Manajemen Public Relations. Jakarta: Pustaka Utama Grafiti.

Keller, K. L. 2013. Strategic Brand Management: Building, Measuring, and Managing Brand Equity, 4nd ed. Prentice-Hall. Upper Saddle River, NJ.

Kuncoro, Mudrajad. 2013. Metode Riset Untuk Bisnis Dan Ekonomi. Yogjakarta: Erlangga.

Kusuma, S, Y. 2014. Pengaruh Brand Experience Terhadap Brand Loyalty Melalui Brand Satisfaction dan Brand Trust Harley Davidson di Surabaya. Jurnal Manajemen Pemasaran Petra. Vol. 2. No. 1.

Lau, Geok Theng dan Sook Han Lee. 1999. Consumer Trust in a Brand and the Link to Brand Loyalty. Journal of Market Focused Management. Vol. 4.

Louis Didier, Lombart Cindy. 2010. Impact of brand personality on three major relational consequences trust, attachment, and commitment to the brand. Journal of Product and Brand Management. Vol. 19. No. 2, pp. 114 130.

Mkhize, L. 2010. The Role Of Self-Concept In Understanding Brand Experience, Brand Attachment And Brand Loyalty In The Consumption Of Premium Clothing Brands, Master Of Business Administration Research Project. Gordon Institute of Business Science, University of Pretoria. Pretoria.

Naidoo, G.M. 2011. An Evaluation Of Branded Retailing On Consumer Behaviour With A Public Relations Context: A Study Of The Influence Of South African Name Brands On Consumer Behaviour. Doctor of Philosophy in Communication Science. University of Zulu land, Durban.

Prastika, Priska Riana. 2016. Pengaruh Hedonic Value dan Utilitarian Value Terhadap Brand Trust dengan Brand Satisfaction Sebagai Variabel Mediasi. Skripsi. Program Studi Manajemen. Universitas Muhammadiyah Purworejo.

Purnamasari, Purbasari. D. W. Anteseden Keterikatan Merek dalam Membangun Hubungan Merek pada Konsumen (Kepercayaan, Kepuasan, dan Komitmen) Terhadap Loyalitas. Jurnal Manajemen. http://docplayer.info/34960459-

Anteseden-keterikatan-merek-dalammembangun-hubungan-merek-padakonsumen-kepercayaan-kepuasan-dankomitmen-terhadap-loyalitas.html Diakses Tanggal 09 Oktober 2019. Pp. 
38-46.

Saini, V.K. 2015. The Role of Brands in Online and Offline Consumer Choice. Doctor of Philosophy thesis, Wits Business School. University of the Witwatersrand, Johannesburg, South Africa.

Shestakov, A. A. 2012. Moderating Role of Brand Attachment in Brand Crisis. To What Extent Does Brand Attachment Affect Purchase Intention in Brand Crisis: A Study Based on Apple's Crisis in China. Master Thesis, Norges Handel shoyskole, Bergen.

Storm, M. 2016. Factors Influencing Involvement, Brand Attachment, and Brand Loyalty on Facebook Brand Pages. Master Thesis, Copenhagen Business School.

Sukoco, Hartawan. 2011. Pengaruh Pengalaman dan Keterikatan Emosional Pada Merek Terhadap Loyalitas Konsumen. Jurnal Manajemen Teori dan Terapan. Vol. 4. No. 3.

Taghipourian, M.J. \& Bakhsh, M. M. 2015. Brand Attachment: Affecting factors and consequences. International Journal of Engineering Research and Management. Vol. 2. No 11, pp. 5-9.

Widikusyanto, J. W. 2014. Peran Keterikatan Merek Dalam Membangun Loyalitas Pelanggan. Jurnal Manajemen. Vol. 4, pp. 49-70.

Zainuddin, F, A. 2018. Pengaruh Brand Prestige dan Brand Familiarty serta Brand Awareness Terhadap Purchase Intention Melalui Perceived Quality
Pada Pengguna Sepeda Motor Merek Yamaha NMAX di Kota Samarinda. Skripsi. Program Studi S-1 Terapan Manajemen Pemasaran, Administrasi Bisnis. Politeknik Negeri Samarinda.

http://federaloil.co.id diakses pada tanggal 15 Agustus 2019.

http://m.bisnis.com diakses pada tanggal 08 Oktober 2019.

http://motorek.wordpress.com diakses pada tanggal 03 November 2019.

https://surabaya.tribunnews.com diakses pada tanggal 15 Oktober 2019.

http://Yamaha-motor.co.id diakses pada tanggal 15 Agustus 2019.

http://otomotif.kompas.com diakses pada tanggal 01 April 2020.

http://kompasiana.com diakses pada tanggal 01 April 2020. 